\title{
Orthotrichum pulchellum Brunt. ex Sm. (Bryophyta) in the Czech Republic. Distribution and ecology.
}

Ivana Marková \& Vítězslav Plášek

Orthotrichum pulchellum Brunt. ex Sm. (Bryophyta) in the Czech Republic. Distribution and ecology. Čas. Slez. Muz. Opava (A), 62:73-82, 2013.

Abstract: Orthotrichum pulchellum was found as a new species of the Czech Republic in the year 2006. Now it is known from the 21 localities. All of them are situated along north-west and west border of the Czech Republic. Distribution and basic information of its ecology are presented.

Key words: Orthotrichum pulchellum, Czech Republic, bryophyta, epiphytes, distribution, expansive species, climate change

\section{Introduction}

Orthotrichum pulchellum, an epiphytic moss from family Orthotrichaceae, which has changed dramatically its distribution area during last 15 years. It was distributed from Spain to Norway, mostly along sea coast and very rarely in inland (Frey et al. 1995). Duell (1984) mention this species from Belgium, Crete, Denmark, France, Germany, Great Britain, Ireland, Netherlands, Norway, Poland, Romania?, Sicily, Spain, Switzerland, Sweden and Yugoslavia. From geographical point of view, Duell (1984) classify the moss as northern oceanic species. Dierssen (2001) subsequently includes the species among mediterranean-boreal and oceanicsuboceanic taxa.

Similar distribution like in Europe, where grow along the west sea coast $O$. pulchellum has in North America too. It grows from southern Alaska to Oregon there (Frahm 2002).

Its spread from the west to the east is well mapped in Germany by Frahm (2002). Orthotrichum pulchellum was historically recorded mainly in sea coast with only few inland localities. Only in 1996 new inland locality was found in Saarland /south-west Germany/ (Frahm 2002). In 2002 the moss was collected at the first time in Saxony (Mueller 2004) and subsequently in 2006 it was found as a new species in the Czech Republic (Plášek et Marková 2007, 2008).

O. pulchellum is included among LC-att taxa in the Red List of the bryophytes of the Czech Republic (Kučera et al. 2012). This subcategory is used for less well known taxa for which there is limited information on their current distribution and the potential threat to them (Kučera et al. 2012).

The names of the bryophytes follow the Check list of the bryophytes of the Czech Republic by Kučera et al. (2012). Phytogeographical characterisation was taken from Hejný et Slavík (1997).

\section{Description of the species and ecological characterisation}

Plants of the species grow to a height of about 1-1,5 cm with loosely-twisted and crisped flexuous leaves when dry. Capsule is exserted, during maturation covered with naked, longitudinally striped calyptra. Peristome has 16 conspicuously orange coloured teeth. For detailed description see Plášek et Marková (2007) and Plášek (2012).

Dierßen (2001) describes Orthotrichum pulchellum as subneutrophyt (bark pH: 5.7 - 7.0), mild mesophyt to xerophyt, mild sciophyt to hight photophyt, mild termophyt, mild nitrophyt, sensitive to atmospheric pollution, which grows on trunk and branches of trees and shrubs in sheltered, but not too heavily shaded places (e.g. along forest roads or streams, on low shrubs communities, and on quarries). The species was recorded mainly in deciduous wet and mesophytic wood (phytocoenologically belongs into order Populetalia albae) or shrub communities (from alliance Sambuco-Salicion capreae). It is a colonist growing in bryophyte association evaluated as Cryphaeetum arboreae (alliance Syntrichion laevipilae). 


\title{
Occurrence of the moss Orthotrichum pulchellum in the Czech Republic
}

\author{
Phytogeographical division: Mesophyticum
}

Phytogeographical province: Mesophyticum Massivi bohemici

\section{Phytogeographical district: 25. Krušnohorské podhůří}

- Krušné hory Mts (NW Bohemia), Lesná settlement, NNE of Chomutov town, on a rowan tree in young

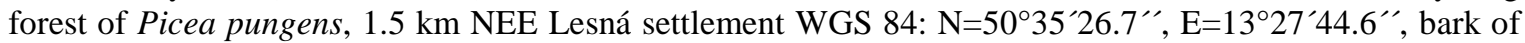
Sorbus aucuparia, 900 m a. s. 1., 15. IX. 2012 leg. \& det. I. Marková, teste V. Plášek, herb. in priv. coll. of I. Marková (No. 2/2012).

Orthotrichum pulchellum was found on the trunk of Sorbus aucuparia at the high of 60 $\mathrm{cm}$ above ground and with SW exposition. Size of the population was about $4 \mathrm{~cm}^{2}$. No accompanying species were observed.there.

\section{Phytogeographical district: 26. Český les}

- Český les Mts, Tachov District, Diana settlement, beech forest, $1.2 \mathrm{~km}$ NEE of Operating building of the Kolowrat forests, WGS-84: N=49³8'21.2", E=12³6'38.2", 525 a. s. 1., 28. V. 2009 leg. R. Mudrová, herb. in priv. coll. of R. Mudrová

\section{Phytogeographical district: 28. Tepelské vrchy}

- Slavkovský les Mts (W Bohemia), Svatošské skály rocks, $5 \mathrm{~km} \mathrm{SW} \mathrm{of} \mathrm{Karlovy} \mathrm{Vary} \mathrm{town,} \mathrm{the} \mathrm{area} \mathrm{of}$ summer camp, $30 \mathrm{~m}$ behind the gate, bark of Acer pseudoplatanus on the right bank of the Ohře river, WGS

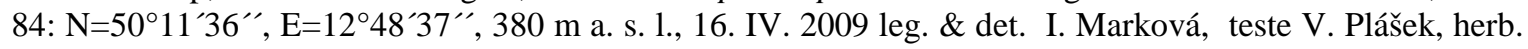
in priv. coll. of I. Marková (No. 18/2009).

Orthotrichum pulchellum was found on the trunk of Acer pseudoplatanus at the high 180 $\mathrm{cm}$ above ground and with NWW exposition. Size of the population was about $1,5 \mathrm{~cm}^{2}$. It was grown together with Ceratodon purpureus and Chiloscyphus profundus there. The record has already been published in Kučera et al. (2009).

\section{Phytogeographical district: 33. Branžovský hvozd}

- Domažlice district (W Bohemia), Kdyně village, $10 \mathrm{~km} \mathrm{SE}$ of Domažlice town, ruin of castle Nový Herštejn, $2.5 \mathrm{~km} \mathrm{NE}$ of Kdyně village, forest, $700 \mathrm{~m} \mathrm{~S}$ of the ruin, on clump of Acer pseudoplatanus near red marked touristic path, $100 \mathrm{~m}$ NNW of cross-road "Vejpřahy - rozcestî", WGS 84: N=49²4'32.585", $\mathrm{E}=13^{\circ} 4^{\prime} 5.420 ", 640 \mathrm{~m}$ a .s. 1., 18. IV. 2013 leg. \& det. I. Marková, herb. in priv. coll. of I. Marková (No. 1/2013).

Orthotrichum pulchellum was found on the trunk of Acer pseudoplatanus at the high of $100 \mathrm{~cm}$ above ground and with NE exposition. Size of the population was about $1 \mathrm{~cm}^{2}$. It grew together with Hypnum cupressiforme var. cupressiforme.

\section{Phytogeographical district: 46. Labské pískovce}

- Bohemian Switzerland National Park, Chřibská town, valley of the Doubický potok stream, loc. "hájenka Saula", $2.5 \mathrm{~km}$ WNW of Chřibská town, bark of Fraxinus excelsior, WGS 84: N=5052’21", $\mathrm{E}=14^{\circ} 26^{\prime} 48^{\prime \prime}, 335$ m a. s. 1., 3. VIII. 2006 leg. I. Marková, det. V. Plášek, herb. in priv. coll. of I. Marková (No. 78/2006).

Orthotrichum pulchellum was found growing on the trunk of Fraxinus excelsior at the high of $205 \mathrm{~cm}$ above ground and with NEE exposition. Size of the population was about $2 \mathrm{~cm}^{2}$. It grew together with Brachythecium salebrosum, Hypnum cupressiforme var. cupressiforme and Orthotrichum pumilum. The record has already been published by Plášek \& Marková $(2007,2008)$.

- Bohemian Switzerland National Park (NW Bohemia), Krásná Lípa town, Medvědice hill, $4.5 \mathrm{~km} \mathrm{~W}$ of Krásná Lípa town, clump of Acer pseudoplatanus on a forest near the meadow, $100 \mathrm{~m}$ SE of the top of the

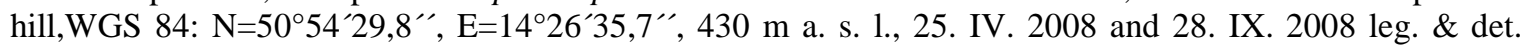
I. Marková, teste V. Plášek, herb. in priv. coll. of I. Marková (No. 27/2008 and No. 130/2008). 
Orthotrichum pulchellum was found on the trunk of Acer pseudoplatanus at the high of 60 $\mathrm{cm}$ above ground and with $\mathrm{N}$ exposition. Size of population was about $4 \mathrm{~cm}^{2}$. It was grown together with Brachytheciastrum velutinum, Chiloscyphus profundus and Hypnum cupressiforme var. cupressiforme. The finding was published in Marková (2008).

- Bohemian Switzerland National Park, Mlýny hill, $2.5 \mathrm{~km}$ NE of Vysoká Lípa village, pile of branches from cutting trees near the asphalt road at the NW slope of the hill, $200 \mathrm{~m}$ below the branch roads going to the

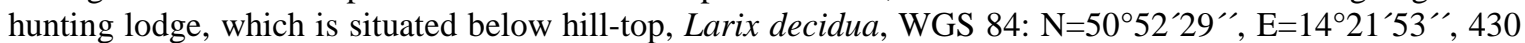
m a. s. 1., 31. V. 2009 leg. \& det. I. Marková, herb. in priv. coll. of I. Marková.

Orthotrichum pulchellum was found at the branches of cutting trees (Larix decidua). Size of population was about $1 \mathrm{~cm}^{2}$. The moss grew together with Orthotrichum sp (sterile). The record has already been published by Marková (2010).

- Bohemian Switzerland National Park, Jetřichovice village, $5 \mathrm{~km}$ NNW of Česká Kamenice town, Dolský mlýn ruin of mill, $3 \mathrm{~km} \mathrm{~W}$ of Jetřichovice village, fallen branch of Salix sp., WGS 84: N=50 $50^{\prime} 26^{\prime \prime}$, E $=14^{\circ} 20^{\prime} 56^{\prime \prime}, 192$ m a. s. 1., 19. III. 2010 leg. \& det. I. Marková, teste V. Plášek, herb. in priv. coll. of I. Marková.

Orthotrichum pulchellum was found on fallen branch of Salix sp. Size of population was about $1 \mathrm{~cm}^{2}$. No accompanying species were recorded there. The record has already been published by Marková (2010).

- Bohemian Switzerland National Park, Kyjov village, 3.5 km W Krásná Lípa town, Brtnický most bridge

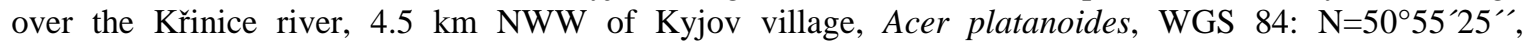
$\mathrm{E}=14^{\circ} 24^{\prime} 10^{\prime \prime}, 340 \mathrm{~m}$ a. s. 1., 3. V. 2010 leg. \& det. I. Marková, teste V. Plášek, herb. in priv. coll. of I. Marková (No 11/2010).

Orthotrichum pulchellum was found on the trunk of Acer platanoides at the high 170 and $180 \mathrm{~cm}$ above ground and with NNW exposition. Two populations were observed there. Size of both populations together was about $12.5 \mathrm{~cm}^{2}$. They grew together with Hypnum cupressiforme var. cupressiforme, Orthotrichum pumilum and Pylaisia polyantha. The record has already been published by Marková (2010).

- Elbe Sandstone Protected Area, Všemily village, "Meandry Chřibské Kamenice" Nature reserve, 500 m E of camp "U Ferdinanda", bark of Prunus padus, on a bank of Chřibská Kamenice river, WGS 84: $\mathrm{N}=50^{\circ} 50^{\prime} 11^{\prime \prime}, \mathrm{E}=14^{\circ} 21^{\prime} 49^{\prime \prime}, 200 \mathrm{~m}$ a. s. 1., 4. V. 2010 leg. \& det. I. Marková, teste V. Plášek, herb. in priv. coll. of I. Marková (No 13/2010).

Orthotrichum pulchellum was found at the inclined trunk of Prunus padus at the high 50 $\mathrm{cm}$ above ground and with SWW exposition. Size of population was $4 \mathrm{~cm}^{2}$. There were no accompanying species. The finding was published in Marková (2010).

- Bohemian Switzerland National Park, Brtníky village, $6 \mathrm{~km}$ SSW of Šluknov town, unused meadow by Brtnický potok stream, $800 \mathrm{~m}$ NE of Brtnický most bridge, $3.5 \mathrm{~km} \mathrm{SW}$ of Brtníky village, bark of Fraxinus excelsior, at margin of the meadow, WGS 84: $\mathrm{N}=50^{\circ} 55^{\prime} 41^{\prime \prime}, \mathrm{E}=14^{\circ} 24^{\prime} 27,1^{\prime \prime}, 300 \mathrm{~m}$ a. s. 1., 22. VII. 2012 leg. \& det. I. Marková, teste V. Plášek, herb. in priv. coll. of I. Marková (No 4/2012).

Orthotrichum pulchellum was found on the trunk of Fraxinus excelsior at the high $62 \mathrm{~cm}$ above ground and with SW exposition. There were found three populations. Their size together was about $2 \mathrm{~cm}^{2}$. No accompanying species were recorded there.

- Bohemian Switzerland National Park, Brtníky village, 6 km SSW of Šluknov town, Severák hill near Kopec settlement, left tributary of Bílý potok stream, forest in a valley of Bílý potok stream, $3 \mathrm{~km} \mathrm{SW}$ Brtníky

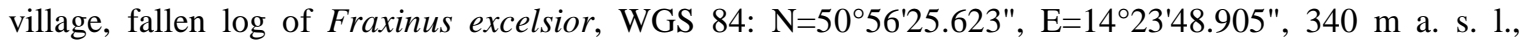
22. VII. 2012 leg. \& det., herb. in priv. coll. of I. Marková (No 5/2012).

Orthotrichum pulchellum was found on a fallen log of Fraxinus excelsior at the high of 30 $\mathrm{cm}$ above ground and with $\mathrm{W}$ exposition. Size of population was about $1 \mathrm{~cm}^{2}$. The moss grew together with Brachythecium salebrosum there. 


\section{Phytogeographical district: 47. Šluknovská pahorkatina}

- Děčín district, Krásná Lípa town, $5 \mathrm{~km} \mathrm{SW}$ of Rumburk town, small forest by local railway $1.7 \mathrm{~km} \mathrm{NW}$ of Krásná Lípa town, bark of Salix viminalis, WGS 84: N=5055.38”, E=14²9.42.3”, 455 m a. s. 1., 15. VIII. 2007 leg. I. Marková, teste V. Plášek, herb. I. Marková (priv. herb. - number 111/2007 and $113 \mathrm{a} / 2007)$.

Orthotrichum pulchellum was found on the trunk of Salix viminalis at the high of 70 and $150 \mathrm{~cm}$ above ground and SWW exposition. Two different populations were observed there. Their size were $4 \mathrm{~cm}^{2}$ and $0.5 \mathrm{~cm}^{2}$. The first population of the moss grew together with Brachythecium salebrosum and Hypnum cupressiforme var. cupressiforme. The second one was observed growing together with Amblystegium serpens, Hypnum cupressiforme var. cupressiforme and Orthotrichum diaphanum. The record has already been published by Plášek \& Marková (2007).

- Lužické hory Protected Area, Krásná Lípa town, 5 km SW of Rumburk town, Široký vrch hill, 3 km SSW of Krásná Lípa town, clump of Acer pseudoplatanus, S of cross-road of "Rovná cesta” way, 508 m a. s. 1., leg. \& det. I. Marková, teste V. Plášek.

Two populations of the species were recorded there on different trees:

i) bark of Acer pseudoplatanus on the back side of clump of trees, $5 \mathrm{~m}$ far from the forest road, WGS

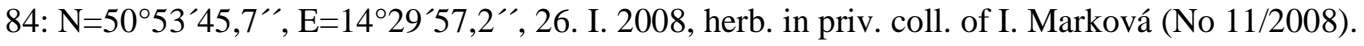

Orthotrichum pulchellum was found on a trunk of Acer pseudoplatanus at the high of 60 $\mathrm{cm}$ above ground and with NWW exposition. Size of the population was about $2.25 \mathrm{~cm}^{2}$. No accompanying species was observed there.

ii) bark of Acer pseudoplatanus, WGS 84: N=5053`47,7”, $\mathrm{E}=14^{\circ} 29^{\prime} 54,4^{\prime \prime}, 6$. VII. 2008, herb. in priv. coll. of I. Marková (No 97/2008).

Orthotrichum pulchellum was found on a trunk of Acer pseudoplatanus at the high of 150 $\mathrm{cm}$ above ground and with NW exposition. Two populations grew there with total size about $1.5 \mathrm{~cm}^{2}$. The population was associated with Brachythecium salebrosum.

The record has already been published by Marková (2008).

- Elbe Sandstone Proteted Area, Kopec settlement, $10 \mathrm{~km}$ SWW of Rumburk town, the valley of Brtnický potok brook, $650 \mathrm{~m} \mathrm{~S}$ of pub "U Vyskočilu’", bark of Acer pseudolpatanus, WGS 84: N=50 56 '36,1", $\mathrm{E}=14^{\circ} 24^{\prime} 49,1^{\prime \prime}, 370 \mathrm{~m}$ a. s. 1., 23. IV. 2008 and 17. VIII. 2008 leg. \& det. I. Marková, teste V. Plášek, herb. in priv. coll. of I. Marková (No 23/2008 and 117/2008).

Orthotrichum pulchellum was found on a trunk of Acer pseudoplatanus at the high of 140 $\mathrm{cm}$ above ground and with E exposition. Size of population was about $2 \mathrm{~cm}^{2}$. The population was associated with Brachythecium salebrosum and Brachytheciastrum velutinum. The record has already been published by Marková (2008).

- Lužické hory Protected Area, Doubice village, Spravedlnost hill, 4.2 km SW of Krásná Lípa town, N slope, fallen tree of Salix caprea on the border of Nature Reserve, near the yellow marked touristic way, WGS 84: $\mathrm{N}=50^{\circ} 52^{\prime} 53,48^{\prime \prime}, \mathrm{E}=14^{\circ} 28^{\prime} 09,36^{\prime \prime}, 470$ m a. s. 1., 27. II. 2011 leg. \& det. I. Marková, teste V. Plášek, herb. in priv. coll. of I. Marková (No. 1/2011).

Orthotrichum pulchellum was found on the fallen log of Salix caprea at the high from 90 till $100 \mathrm{~cm}$ above ground and with NE exposition. Total 10 different populations were observed there. Size of all population together was about $22.5 \mathrm{~cm}^{2}$. The species grew together with Amblystegium serpens, Brachythecium salebrosum, Hypnum cupressiforme var. cupressiforme and Ulota sp. (steril.). The record has already been published by Marková (2011).

- Děčín district, Šluknov town, arboretum of High school of Forestry near Kunratice village, $2.5 \mathrm{~km}$ SSW Šluknov town, bark of Celtis australis, WGS 84: N=5059'4.850"; E=14²6'41.324", 380 m a. s. 1., 13. VI. 2011 not. I. Marková.

Orthotrichum pulchellum was found on the west side of a trunk of Celtis australis there. Size of the population was about $0.25 \mathrm{~cm}^{2}$. It grew together with Brachythecium salebrosum. 
- Děčín district, Rumburk town, Dymník hill, $2.5 \mathrm{~km} \mathrm{SW}$ of Rumburk town, in the forest situated SW of Dymník hill, along the bike way No. 3014, between yellow and blue market touristic way, bark of Quercus

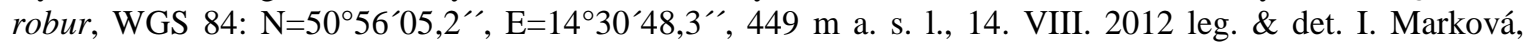
herb. in priv. coll. of I. Marková (No 10/2012 - monitoring).

Orthotrichum pulchellum was found on the trunk of Quercus robur at the high $145 \mathrm{~cm}$ above ground and with E exposition. There were occurred four different populations. Their size together was $3 \mathrm{~cm}^{2}$. On next oak the species was recorded too. Its size was about 1.84 $\mathrm{cm}^{2}$. No accompanying species was observed there.

\section{Phytogeographical district: 50. Lužické hory}

- Lužické hory Protected Area, Česká Kamenice town, Studenec hill, 4 km NNE of the town, cross-road called "Sedlo pod Studencem", cross of red and blue marked touristic ways.

Two populations were recorded there:

i) Acer pseudoplatanus near the cross-road called "Sedlo pod Studencem", WGS 84: N=5049'47,2", $\mathrm{E}=14^{\circ} 27^{\prime} 52,9^{\prime \prime}, 600$ m a. s. 1., 27. V. 2007 leg. \& det. I. Marková, teste V. Plášek, herb. in priv. coll. of I. Marková (No 61/2007).

Orthotrichum pulchellum was found on the trunk of Acer pseudoplatanus at the high 130 $\mathrm{cm}$ above ground and with NWW exposition. Size of population was $4 \mathrm{~cm}^{2}$. The population was associated with Orthotrichum pumilum. The record has already been published by Plášek et Marková (2007).

ii) Fraxinus excelsior in the meadow, $830 \mathrm{~m} \mathrm{SE}$ of the top of Studenec hill, WGS 84: N=5049'55, $5^{\prime \prime}$, E=14²7’56,6”, 614 m a. s. 1., 3. VIII. 2008 leg. \& det. I. Marková, teste V. Plášek, herb. in priv. coll. of I. Marková (No 160/2008).

Orthotrichum pulchellum was found on the trunk of Fraxinus excelsior at the high 13 - 20 $\mathrm{cm}$ above ground and with NEE exposition. Six different populations grew there with total size about $20 \mathrm{~cm}^{2}$. The species was observed together with lichen Physcia sp. and moss Brachythecium salebrosum. The record has already been published by Marková (2008).

Phytogeographical division: Oreophyticum

Phytogeographical province: Oreophyticum Massivi bohemici

\section{Phytogeographical district: 85. Krušné hory}

- Krušné hory Mts, Načetín village, NNW of Chomutov town, a settlement situated about $2.5 \mathrm{~km}$ WNW of

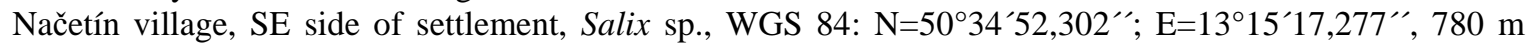
a.s.l., 25. IX. 2010 leg. S. Biedermann, herb. in priv. coll. of S. Biedermann.

The record has already been published by Novozámská et Biedermann (2011).

- Krušné hory Mts, Kovářská village, NW of Klášterec nad Ohř́i town, by the way from train station to limepit, bark of Acer sp., Salix sp., Sorbus sp., WGS 84: N=50²5'42.712", E=13²'42.325", 870 m a.s.1., 25. VII. 2011 leg. S. Biedermann, herb. DR. 


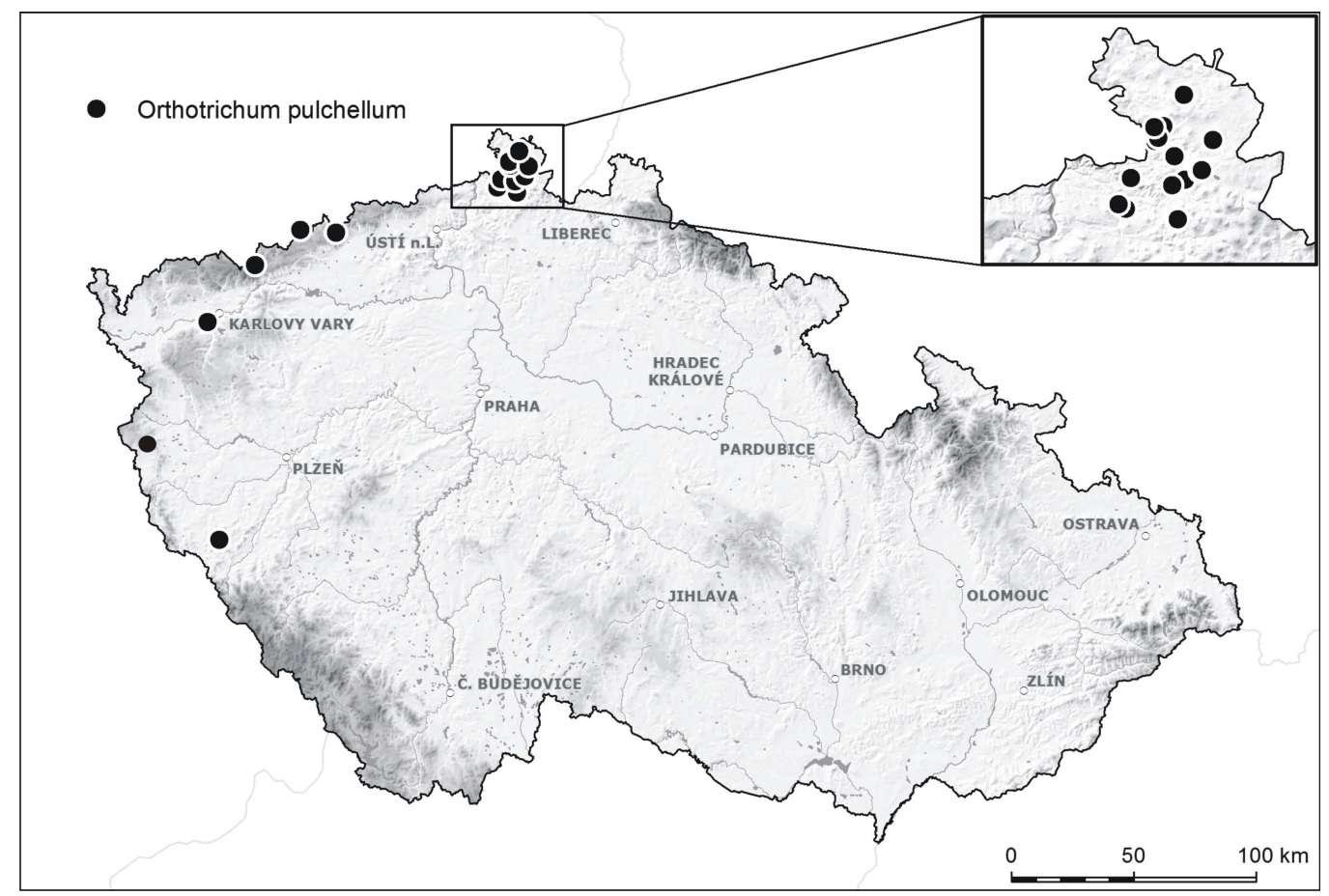

Map 1: Distribution of the moss Orthotrichum pulchellum in the Czech Republic

\section{Discussion}

In the Czech Republic the moss Orthotrichum pulchellum was found on 21 localities till present. All of them are situated along northern, north-western and western border of the country. The most of localities are situated between altitudes of $300-500 \mathrm{~m}$ a. s. 1 . The lowest locality occurs at the elevation 192 m a. s. 1. in Dolský mlýn (Bohemian Switzerland National Park) and the highest locality is placed at the elevation about $900 \mathrm{~m}$ a. s. 1. in Lesná settlement (Krušné hory Mts). These localities are situated in the area with higher than average of rainfall - from 700 - 1000 mm (Míková et al. 2007). It seems the oceanic species prefers areas of high precipitation above $700 \mathrm{~mm}$. Number of known Czech localities is far from final and our knowledge corresponds to sampling effort of the each region. It can be assumed increasing of the number of the localities in Krušné hory Mts considering the intensive bryological research - see Meinunger et Schröder (2007).

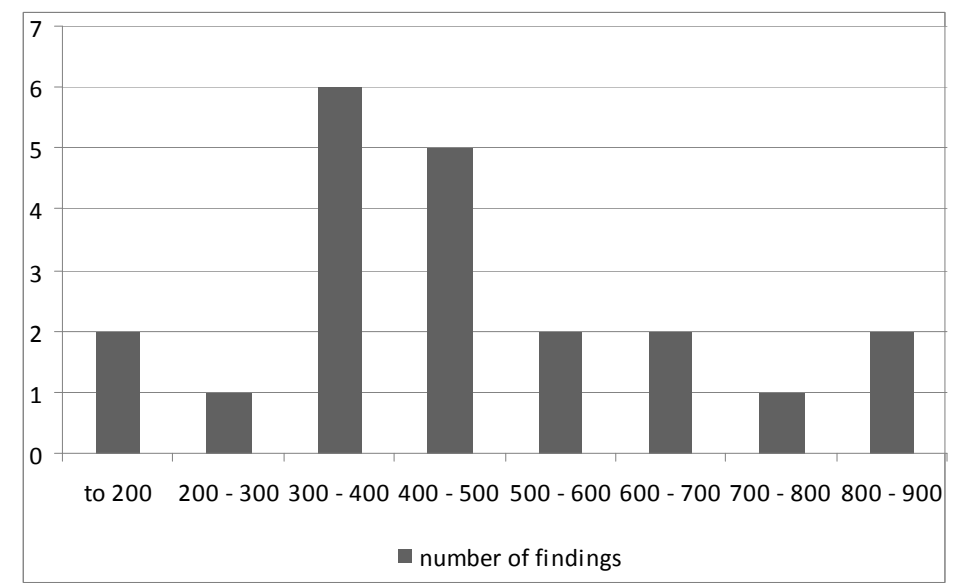

Fig 1: Vertical distribution of Orthotrichum pulchellum (meters above sea leavel). The lowest locality - Dolský mlýn (Bohemian Switzerland National park) $192 \mathrm{~m}$ a. s. 1. The highest locality - surrounding of Lesná settlement (Krušné hory Mts.) 900 m a. s. 1 . 
Orthotrichum pulchellum was found on 9 species of phorophytes. Most frequently it grows on bark of Acer pseudoplatanus, Salix sp. div. and Fraxinus excelsior. Whereas Frahm (2002) mention, as the most frequently species Sambucus nigra, Salix sp. and Populus sp. These data correspond with characteristic pronounced in Dierßen (2001). He mentions $O$. pulchellum as a species of mesophytic forests (order Populetalia albae) or shrub communities (alliance Sambuco-Salicion capreae). In Great Britain it grows most frequently on bark of Salix (Atherton et al. 2010).

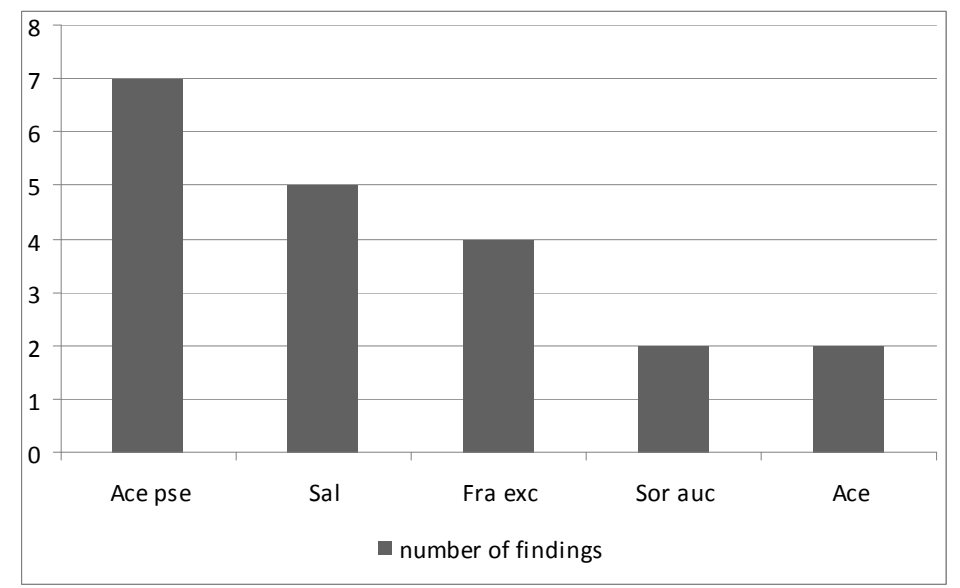

Fig 2: Distribution of Orthotrichum pulchellum on bark of different phorophytes (Ace pse - Acer pseudoplatanus; Sal - Salix sp. div.; Fra exc - Fraxinus excelsior; Sor auc - Sorbus aucuparia; Ace - Acer platanoides). Only once was O. pulchellum found on Celtis australis, Larix decidua, Prunus padus and Quercus robur.

The Czech populations occured mostly at the height of $50-200 \mathrm{~cm}$ above ground. The lowest situated population was recorded at height of $13 \mathrm{~cm}$ and the highest at $205 \mathrm{~cm}$ above ground. A lot of cushions grew with south-western, north-western and north-eastern exposition.

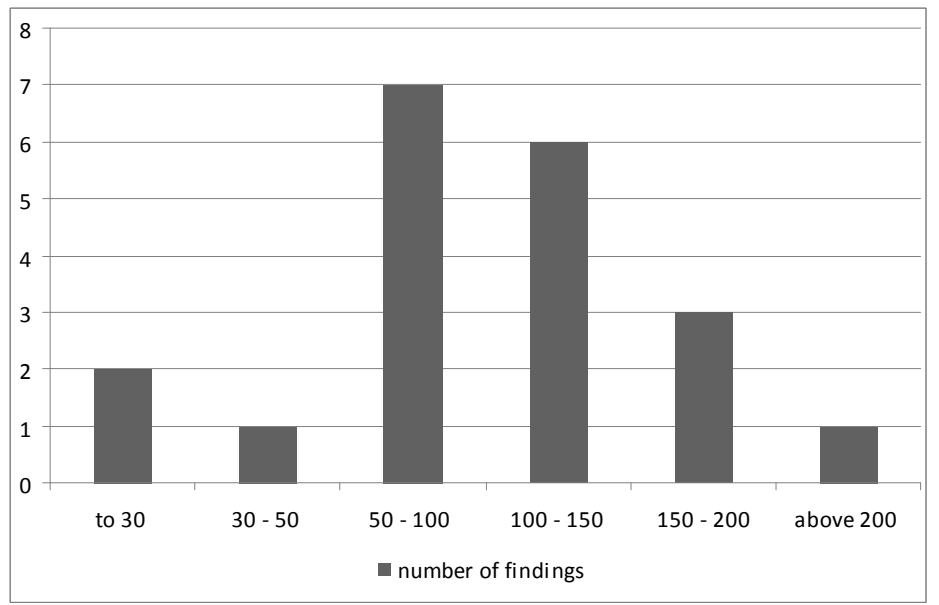

Fig 3: Vertical distribution of Orthotrichum pulchellum on the trunk of tree ( $\mathrm{cm}$ above ground). The lowest position was recorded at the high of $13 \mathrm{~cm}$ and the highest at the high of $205 \mathrm{~cm}$ above ground.

Orthotrichum pulchellum forms small cushions of size about $1-5 \mathrm{~cm}^{2}$. The smallest observed population had surface only about $0.04 \mathrm{~cm}^{2}$ and the largest one about $22.25 \mathrm{~cm}^{2}$ (sum of surfaces of all metapopulations in one phorophyte). 


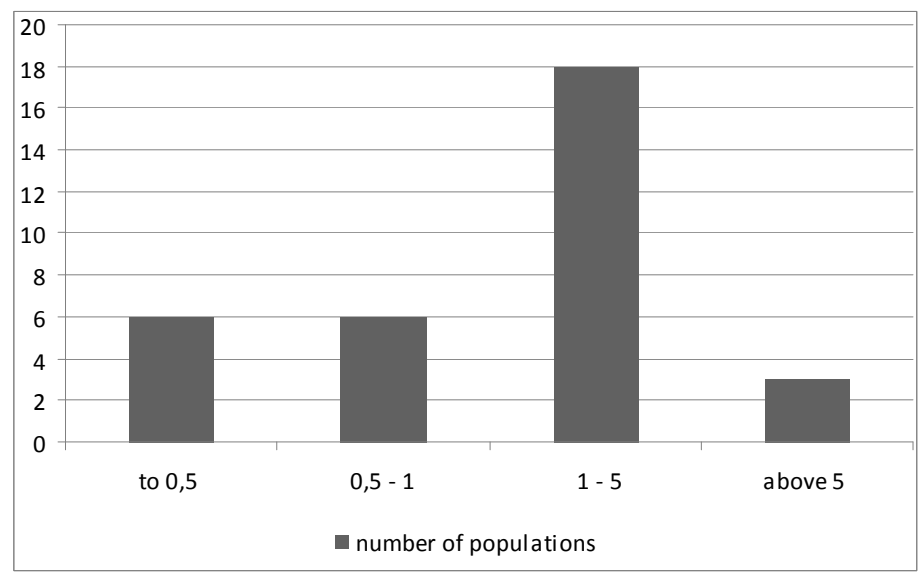

Fig 4: size of the populations of moss Orthotrichum pulchellum (in $\mathrm{cm}^{2}$ ). The smallest population occupied about $0.04 \mathrm{~cm}^{2}$. The largest population occupied about $22.25 \mathrm{~cm}^{2}$ (as a sum of different smaller populations on one tree).

All the populations were observed with sporogones. It grows commonly with accompanying species, often with Brachythecium salebrosum, Hypnum cupressiforme var. cupressiforme and other species from Orthotrichum genus.

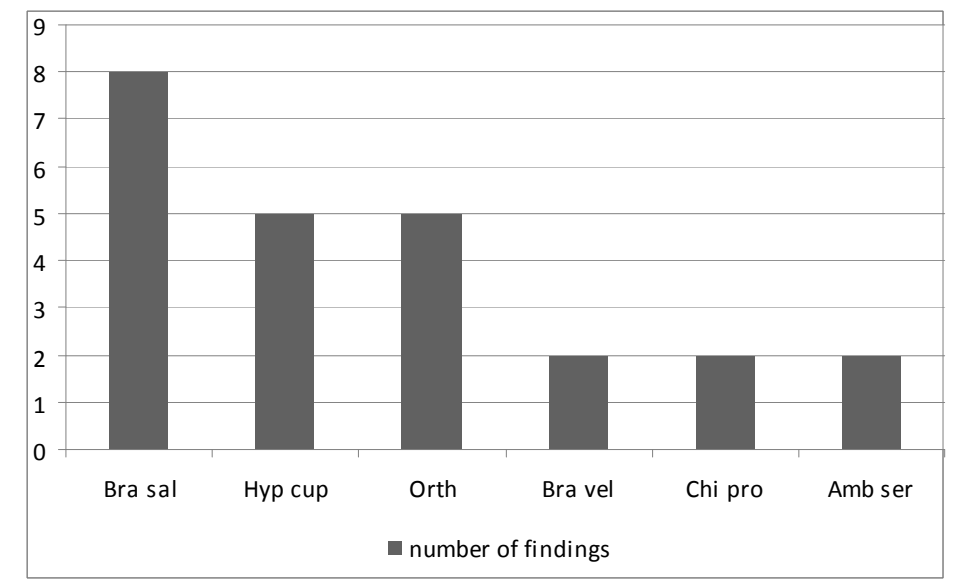

Fig 5: Accompanying species - presence of different taxons (Bra sal - Brachythecium salebrosum; Hyp cup Hypnum cupressiforme var. cupressiforme; Orth - Orthotrichum sp. div.; Bra vel - Brachytheciastrum velutinum; Chi pro - Chiloscyphus profundus; Amb ser - Amblystegium serpens). Mosses Ceratodon purpureus, Pylaisia polyantha, Ulota sp. and lichen Physcia sp. were noted only once as the accompanying species.

Orthotrichum pulchellum has suddenly begin to increase its areal in the last 15 years. In Great Britain dramatic upsurge of the abundance of $O$. pulchellum was observed (Atherton et al. 2010). In Germany the species occurrs in all federal state now (Meinunger 2007). Spreading of $O$. pulchellum is given in the context of i) the improvement of air quality in Central Europe, ii) climate changes (Frahm 2002). These factors are intertwined. The improvement of air quality helps to return of the species to its historic localities and withal surviving on new localities. The climate change allows spreading of the species eastward. Orthotrichum pulchellum as a (sub) oceanic species required mild winter temperature, humid climate or high precipitation. All of these factors correspond to conditions in the known Czech localities. Míková et al. (2007) mention, that annual average of temperature varied strongly between $1961-2000$ with a statically significant warming trend of about $0,03^{\circ} \mathrm{C}$ per year, warming is more noticeable in winter and spring, but negligible in autumn. These 
warming and high precipitation are conductive to spreading of Orthotrichum pulchellum towards the Central Europe.

In the Czech Republic O. pulchellum is included among LC-att taxa in the Red List of the bryophytes of the Czech Republic (Kučera et al. 2012). This subcategory is used for less well known taxa for which there is limited information on their current distribution and the potential threat to them (Kučera et al. 2012).

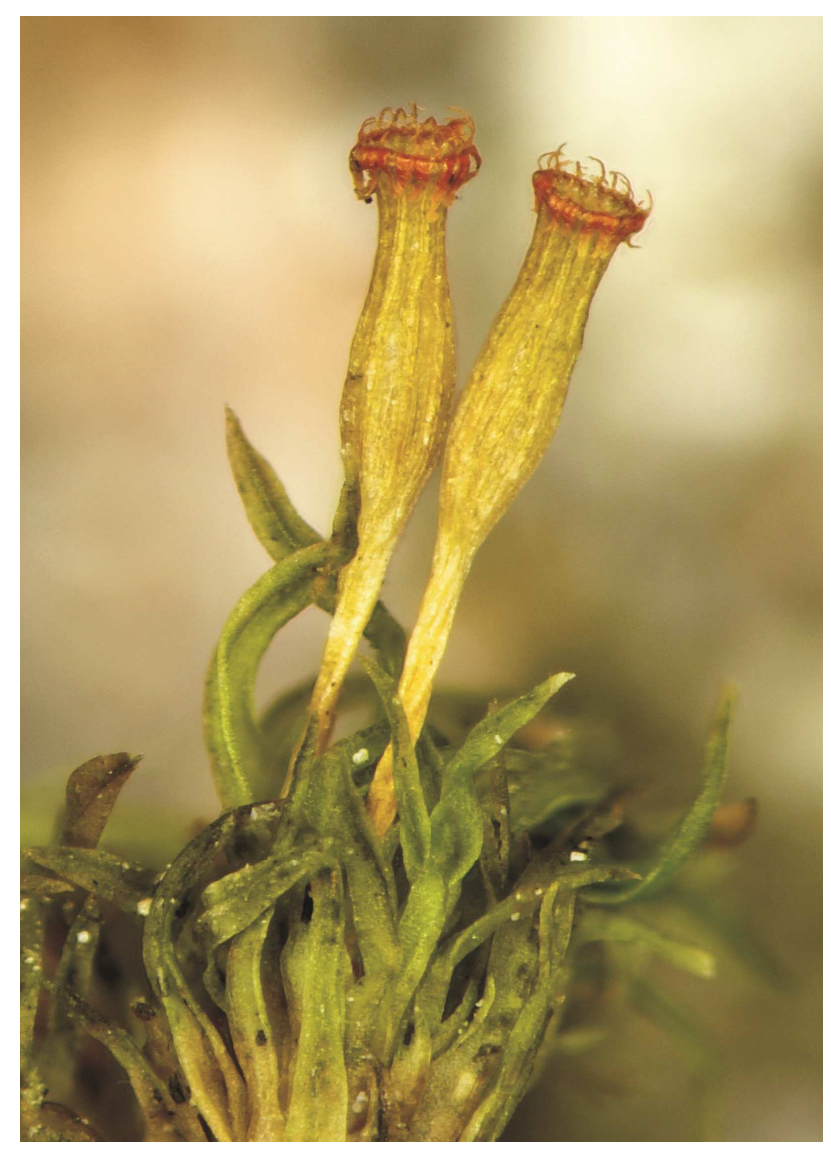

Fig 6: Fertile plants of the moss Orthotrichum pulchellum (photo by V. Plášek)

Acknowledgement: The study has been carried out in connection with the project of the Institute of Environmental Technologies, reg. no. CZ.1.05/2.1.00/03.0100 supported by the Research and Development for Innovations Operational Program, financed by Structural Funds of the European Union and the state budget of the Czech Republic. Field survey was partially supported by SGS grant of University of Ostrava No. 22/PřF/2013. The authors would like to express their gratitude to all those who help. Mainly to Oldřich Holešinský from Bohemian Switzerland National Park Administration for help with preparing of Orthotrichum pulchellum distribution map.

\section{References}

Atherton I., Bosanquet S. \& Lawley M. (2010): Mosses and Liverworts of Britain and Ireland a field guide. British Bryological Society, Plymouth, 848 pp.

Duell R. (1984): Distribution of the European and Macaronesian mosses (Bryophytina), Part I, Bryologische Beitraege, Band 4, Rheurdt, $232 \mathrm{pp}$.

Dierßen (2001): Distribution, ecological amplitude and phytosociological characterization of European bryophytes. - Bryophytorum Bibliotheca, Band 56, J. Cramer, Berlin, Stuttgart, 289 pp.

Frahm J.-P. (2002): Zur aktuellen Verbreitung von Orthotrichum pulchellum. - Bryol. Rundbriefe 52: 1-5.

Frey W., Frahm J.-P., Fischer E. \& Lobin W. (1995): Moos- und Farnpflanzen - Kleine Kryptogamenflora, Band IV, 6. Aufl., Gustav Fischer Verlag, Stuttgart, Jena, New York, 426 pp.

Hejný S. \& Slavík B. (1997): Květena České republiky I., 2. vyd., Academia, Praha, 557 pp. 
Kučera J., Váňa J. \& Hradílek Z. (2012): Bryophyte flora of the Czech Republic: update of the checklist and Red List and a brief analysis. - Preslia 84: 813-850.

Kučera J., Cykowska B., Kubešová S., Kučerová V., Manukjanová A., Marková I., Mikulášková E. \& Vicherová E. (2009): Mechorosty zaznamenané během 16. jarního setkání bryologickolichenologické sekce ČBS ve Svatošských skalách na Karlovarsku. (Bryophytes recorded during the $16^{\text {th }}$ Spring Meeting of the Bryological and Lichenological Section of the CBS in Svatošské skály near Karlovy Vary (W Bohemia). - Bryonora 43: 3-11.

Marková I. (2008). Orthotrichum pulchellum. In Kučera J. [ed.], Zajímavé bryofloristické nálezy XII. (Interesting bryofloristic records, XII). - Bryonora 42: 40.

- (2010). Orthotrichum pulchellum. In Kučera J. [ed.], Zajímavé bryofloristické nálezy XV. (Interesting bryofloristic records, XV). - Bryonora 45: 44.

- (2011). Orthotrichum pulchellum. In Kučera J. [ed.], Zajímavé bryofloristické nálezy XVII. (Interesting bryofloristic records, XVII). - Bryonora 47: 58.

Meinunger L. \& Schröder W. (2007): Verbreitungsatlas der Moose Deutschlands, Band 3. Regensburgische Botanische Gesellschaft, Regensburg, 709 pp.

Míková T., Valeriánová A. \& Voženílek V. (2007): Atlas podnebí Česka (Climate atlas of Czechia), ČHMÚ Praha, UP Olomouc, 255 pp.

Mueller F. [ed.] (2004): Verbreitungsatlas der Moose Sachsens. Lutra Verlag, Tauer, 309 pp.

Novozámská E. \& Biedermann S. (2011): Orthotrichum rogeri. In Kučera J. [ed.], Zajímavé bryofloristické nálezy XVII. (Interesting bryofloristic records, XVII). - Bryonora 47: 58-59.

Plášek V. (2012): Klíč pro determinaci zástupců rodů Orthotrichum a Nyholmiella v České republice. Bryonora 50: 17-33.

Plášek V. \& Marková I. (2007): Orthotrichum pulchellum (Orthotrichaceae, Musci), new to the Czech Republic. - Acta Musei Moraviae 92: 223-228.

- (2008): Orthotrichum pulchellum - In: Ellis L. [ed.]: New national and regional bryophyte records, 18. Journal of Bryology 30: 161-167.

Authors' address: Ivana Marková, Bohemian Switzerland National Park Administraniton, Pražská 52, CZ-407 46 Krásná Lípa, Czech Republic. E-mail: i.markova@npcs.cz

Vítězslav Plášek, Dept. of Biology and Ecology, University of Ostrava, Chittussiho 10, CZ-710 00 Ostrava, Czech Republic.E-mail: vitezslav.plasek@osu.cz 